\title{
O Ano Internacional da Química fol o Ano das Tabelas Periódicas!
}

No número 122 do QUÍMICA, tive a belíssima oportunidade de dar conta de uma nova Tabela Periódica ilustrada (Figura 1) [1]. Esse trabalho foi promovido pela revista Chem 13 News, em parceria com alunos de diversas escolas e de diferentes países, estando Portugal representado convenientemente pela Escola Secundária Infante D. Henrique, no Porto [2].

No entanto, o ano 2011 foi um ano de inspiração artística na área da Química. É com imenso gosto que comunico mais uma Tabela Periódica ilustrada! Desta feita, o projeto ficou a cargo do Royal Australian Chemical Institute, a voz da Química na Austrália, coordenado por Carolyn Canty e por Vicki Gardiner.

A sua celebração do Ano Internacional da Química ficou marcada pela contribuição de 79 químicos e 38 ilustradores na criação de uma Tabela Periódica com bonitas ilustrações - Periodic Table on Show (Figura 2). A cada ilustrador foram atribuídos três elementos químicos escolhidos aleatoriamente e a parceria entre químicos e ilustradores faz-se sentir na qualidade das cento e doze obras que podem ser consultadas online [3].

Os ilustradores envolvidos no projeto possuíam variados graus de experiên- cia artística. Contribuíram neste projeto ilustradores profissionais, estudantes da Escola de Artes e outros profissionais que possuíam experiência e sensibilidade artística. Eles utilizaram diversas formas de se expressarem artisticamente, desde impressão em relevo a litografia, passando por técnicas mais contemporâneas como o desenho digital.

Cada obra artística (ou cada elemento químico, como preferir) é acompanhada por um texto enquadrador em que são apresentados pormenores históricos da descoberta do elemento, as aplicações mais comuns do mesmo, bem como outros pormenores que vale a pena conhecer.

Será curioso até mesmo comparar a participação portuguesa no primeiro projeto (com o elemento químico európio) com o contributo australiano. É importante referir que, em ambos os projetos, cada elemento possui uma ficha de consulta com um pequeno texto onde figuram alguns pormenores científicos, muito embora o projeto com participação portuguesa possua, para cada elemento, dados úteis como a massa atómica, eletronegatividade, entre outros.

Assim, comparando o trabalho resultante do projeto da revista Chem 13
News com o do Royal Australian Chemical Institute, fica a pergunta no ar: Qual foi a Tabela Periódica mais bonita do Ano Internacional da Química?

Em suma, o Ano Internacional da Química não foi apenas um ano de celebração mas também um ano de expressão artística científica no seu mais alto nível. Façamos votos de que os próximos anos que estão para vir sejam de bom trabalho químico aqui em Portugal e em todo o mundo.

\section{REFERÊNCIAS}

[1] D. Ribeiro, Uma Nova Tabela Periódica no Ano Internacional da Química, Química - Bol. S.P.Q. 122 (2011) 25-26.

[2] Periodic Table Project: http://chemistry. uwaterloo.ca/iyc/periodic-table-project (Department of Chemistry of the University of Waterloo, acedido em 12-012012).

[3] Periodic Table: http://www.raci.org.au/ periodic-table-on-show (The Royal Australian Chemical Institute Incorporated, acedido em 12-01-2012).

Daniel Ribeiro

(danieltiago.ribeiro@gmail.com) Licenciado em Química e Mestre em Ensino da Física e da Química

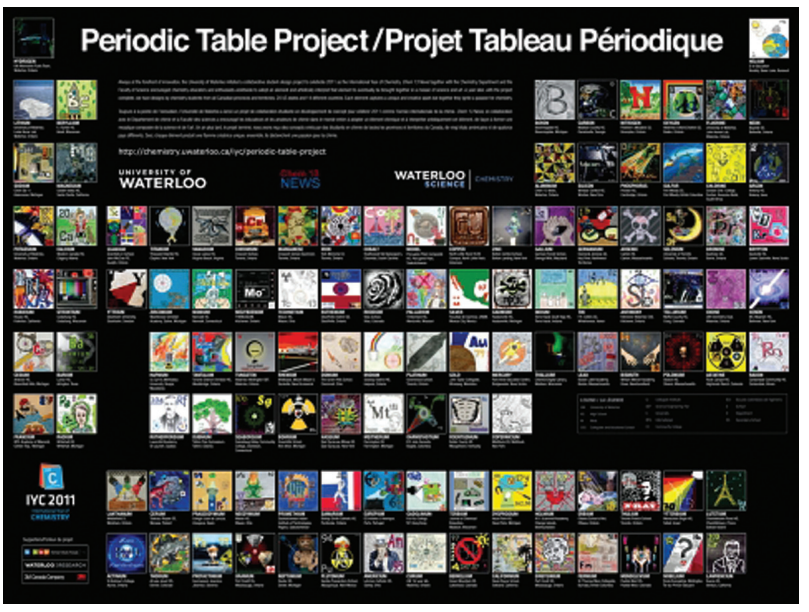

Figura 1 - A Tabela Periódica resultante do projeto da revista Chem 13 News

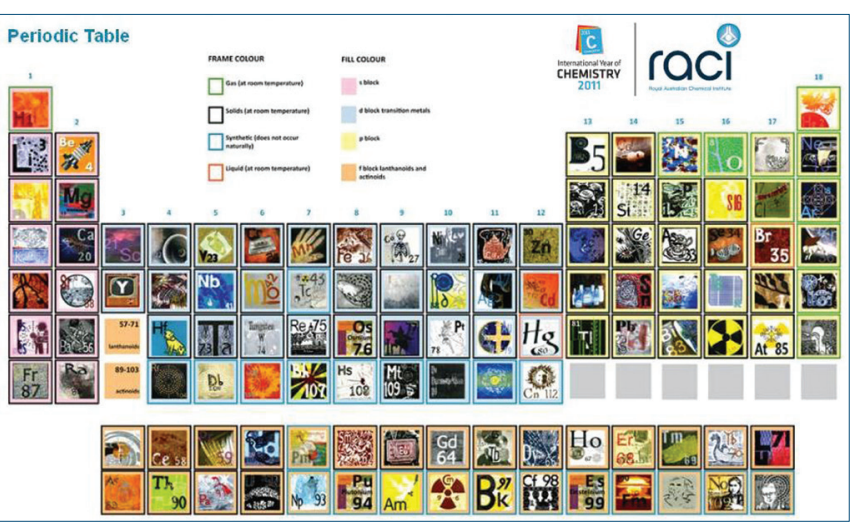

Figura 2 - A Tabela Periódica resultante do projeto do Royal Australian Chemical Institute 


\section{$3{ }^{1}$ 3rd Portuguese Young \\ Chemists Meeting}

9-11 ${ }^{\text {th }}$ May 2012

FACULDADE DE CIÊNCIAS

UNIVERSIDADE DO PORTO 